\title{
Renewed Patronage and Strengthened Authority of Chiefs Under the Scarcity of Customary Land in Zambia
}

\author{
Shuichi Oyama
}

\begin{abstract}
The Zambian government enacted the 1995 Lands Act with the aim of stimulating investment and agricultural productivity. This Act strengthened the role and power of traditional leaders, particularly chiefs, as it empowered them to allocate customary land to individuals and companies, including foreign investors. In the Bemba chiefdom of northern Zambia, a new chief issued new land rights and invalidated the land rights issued by the old chiefs. As a result, land owners with documents in the old formats were required to obtain new certification from the new chief. Concerned about the land within his territory, this chief also decided to invalidate the title deeds issued by the central government so that he could release the protected land to local people. Alongside their historical and cultural power, the chiefs strengthened their patronage over land distribution as well as their authority over the residents in their territories. With high demand for land, anxiety among local people due to land scarcity has created political power and authority for the chiefs.
\end{abstract}

Keywords Customary land · Development $\cdot$ Lands Act $\cdot$ Bemba $\cdot$ Traditional leaders $\cdot$ Chiefdom

\section{Introduction}

Across much of Africa, economic, demographic, and environmental changes are straining political and social rules governing land access and land use in rural areas (Gulliver 1961; von Blanckenburg 1993; Moyo 2007; Boone 2014). Land policy reform in Africa is a process played out between the state and traditional leaders regarding customary land administration and management (see Chap. 3). In Zambia, the enactment of the 1995 Lands Act clearly stipulated the need for land ownership rights to customary land to be in writing (ie, the acquisition of title deeds) for the first time. The Act stipulated that the acquisition of title deeds necessitated the approval of traditional leaders, such as chiefs and village headmen, regardless of whether the

\footnotetext{
S. Oyama $(\varangle)$

Centre for African Area Studies, Kyoto University, Kyoto, Japan

e-mail: oyama.shuichi.3r@kyoto-u.ac.jp
} 
person seeking to acquire the land was a resident of the region or an outsider. The Lands Act therefore made it possible for affluent Zambians, foreign companies, and other wealthy actors to acquire title deeds and customary land from the Ministry of Lands, as long as they obtained the approval of traditional leaders. This in turn encouraged economic activity by companies and individuals on customary land and changed local perceptions of the economic value of land.

Ault and Rutman (1993) provided an overview of the changes in customary land tenure in east and southern Africa from the twentieth century onward. They found that when customary land was abundant and perceived to have little economic value, individuals used it free of charge through a system of customary land ownership without having to be aware of or abide by laws or the customs of various ethnic groups. Over time, customary land became rarer and the legal regimes of various countries came to recognise and emphasise individuals' rights to land use. This change from a system of customary land tenure to private ownership meant that chiefs' authority over customary land was sometimes lost or overlooked.

Chiefs were aware that privatisation of customary land reduced their authority over the land. This made them suspicious of the 1995 Lands Act and led them to voice their opposition, noting specifically the potentially negative impact on their own authority (Brown 2005). However, the Act actually strengthened chiefs' authority over the land by mandating their approval for the acquisition of title deeds and giving them the power to grant land rights and distribute land themselves.

In December 2012, Zambian President Michael Sata of the Patriotic Front party gave a speech that emphasised the chiefs' role in promoting the development of rural areas (Times of Zambia 2012a, b). According to his policy, traditional leaders are at the core of the regional development undertaken by the current Zambian government. While this has enhanced their autonomy over the land, the regional development promoted by chiefs and other traditional leaders has created some controversy. They often attempt to walk the line between providing for their community and opening their land up for investment. For example, in the densely populated areas of Kasama District in Northern Province, the chief of the Bemba chiefdom led a programme of compulsory land partitioning and distribution of 3 ha to each household in the region. He also provided 100 ha to foreign companies for the construction of oil refineries, power stations, and shopping malls (Zambia Daily Mail 2016). The chief welcomed calls for large-scale development projects and provided large land holdings for such projects.

In short, because chiefs need to approve the acquisition of title deeds, they hold some measure of authority over the promotion of economic development in the region (Oyama 2016). Kajoba (2004) asserted that by collaborating closely with chiefs, the Zambian government is able to recognise the land rights of both locals and foreign investors more fully, while also empowering chiefs to participate proactively in sustainable community development. In reality, it has proven difficult to reconcile the interests of the local subjects and outside investors. Granting foreign investors the right to their land puts local communities at risk of having their land taken from them, seeing their living standards reduced, and raises the risk of land-related conflict (Oyama 2016). 
Given these changes in Zambian land policy, this chapter describes the granting of land rights by successive generations of chiefs in the territory of Chief L in the Bemba chiefdom of northern Zambia and examines the social confusion accompanying such grants. It then analyses how, in the event that a new chief is appointed, newlyappointed chiefs and land committees deal with the social confusion created over successive generations of chiefs. It also considers the autonomy of chiefs and local authorities with respect to land governance by examining the chiefs' creation of new land rights and their invalidation of title deeds issued by the Zambian state.

This chapter arose out of the author's continuous field research in the Bemba chiefdom since 1993. As such, it provides a well-grounded and detailed analysis of the complex relationships between the state and the traditional leaders of the Bemba chiefdom, which is ruled by a centralised, authoritarian-style chieftain system. It considers the impact of this system on rural development, the transformation of farming village communities, and the future of the local inhabitants. In summary, this chapter clarifies the effects of the 1995 Lands Act on farming village communities in Zambia, and considers how the Lands Act has strengthened the authority of traditional leaders over the land.

\section{Land Tenure System in Zambia}

As a result of the Lands Act of 1995, all land in Zambia is currently owned by the state. Some of this land is customary land, which is prescribed in accordance with the customs and norms of each ethnic group, and some is private land, which is prescribed by title deeds. This section will briefly examine changes in the land tenure system since Zambia's colonial period with reference to the existing literature (Roberts 1976; Mvunga 1980; Chanock 1998; Brown 2005; Oyama 2016).

In 1911, the colonial territories of North-eastern Rhodesia and North-western Rhodesia were merged to produce the territory of Northern Rhodesia. This territory contained the lands of the Bemba chiefdom (or Bembaland). Between 1899 and 1911, North-eastern Rhodesia was ruled by the British South African Company (BSAC). In 1911, an Order-in-Council recognised the British monarchy's right to the territory of Northern Rhodesia (Mvunga 1980). This happened again in 1924, when the territory was officially placed under the administration of a British-administered colonial government. The colonial government defined the land held by European settlers, commercial and residential land in urban areas, and land containing high-quality mining resources as Crown Land (Brown 2005). Another Order-in-Council in 1928 separated Crown Land from Native reserves, and established the latter as land for use by Africans who had been driven out of their former lands by European settlement (Mvunga 1980). The creation of this reserve system was meant to encourage European settlement in Northern Rhodesia.

However, settlement did not proceed as expected. For the colonial government to continue to govern the vast territories of Northern Rhodesia as Crown Land under its direct control, it needed to create several administrative organisations at a high 
economic cost. To reduce administrative costs, in 1947 the colonial government converted the large majority of Crown Land, especially land that was poor in mining resources and fertility, to Trust land and introduced a system of indirect governance, which entrusted traditional leaders with political authority over Trust land. Rural African subjects were governed by chiefs and customs, and lived on spatially distinct communal land. In contrast, European settlers and urban dwelling citizens were governed by modern civil law and owned or rented private property (Mamdani 1996). Almost all of Bembaland was made into Trust land. In this way, the authority of the Bemba chiefs was strengthened by the colonial government.

Zambia declared its independence in 1964. However, the new Zambian state inherited the land administration framework that had been established during the colonial period (Mvunga 1980, 1982; Malambo 2013). The administration of Kenneth Kaunda, the first president of Zambia, converted land that had been Crown Land during the colonial period into state land to ensure that all of Zambia belonged to the state and Britain held no sovereignty over the land. Under the Kaunda regime, national territory was classified into three types of land: State land, Reserves, and Trust land. Although the term 'native' was removed from the official description of the Reserves, the chief of each ethnic group continued to hold authority over Reserves and Trust land.

After 1964, Reserves and Trust land were placed under the control of local assemblies, ie, the newly independent Zambian state stripped chiefs of their authority over their lands. However, the government did not abolish chiefs or village heads and they continued to hold influence as traditional leaders. The Zambian Constitution was amended in 1969. In these amendments, the government permitted the confiscation of undeveloped land, especially land that was not being used by absentee landlords. Later, the Lands Act of 1975 stipulated that 'all land in Zambia shall vest absolutely in the President and shall be held by him in perpetuity for and on behalf of the people of Zambia'. This Act did not recognise private land in the sense of permanent ownership of land, and cases of freehold tenure were converted into 100-year leaseholds.

In 1985, legislation was passed that restricted the distribution of Zambian land to foreigners, with the exception of investors and companies recognised by the presidential government. Thus, although the trading of customary land was legally possible prior to the 1995 Lands Act, the procedures for obtaining ownership of customary land were unclear. Private land owners often acquired customary land by applying for a title deed through the Ministry of Lands and, therefore, most private land owners were politicians, bureaucrats, members of the army, police, or other people who had connections with or within the Ministry of Lands.

The 1995 Lands Act was first enacted by the Movement for Multiparty Democracy (MMD) during Zambia's open elections in 1991. The MMD pledged to establish legislation to introduce market mechanisms to the land acquisition system in Zambia. Such legislation was also deliberated upon and passed as a condition for foreign debt relief in Zambia by some donor countries. The 1995 Lands Act had three main characteristics. First, it significantly reinforced the right of title deeds. While land belonged to the President and freeholding was not recognised, article 6 of 
the Lands Act provided leaseholds for a 99-year period. This, in addition to Article 5's permission for the sale and purchase of leaseholds, shows that the Act may be interpreted as essentially recognising private land ownership. Second, Article 3(3) of the Act relaxed restrictions related to the possession of land by foreign individuals and companies. This actively introduced foreign capital and was closely connected to the Zambian government's intention to promote economic development. Third, the Lands Act consolidated both Reserves and Trust land into customary land (Article 2), and made it possible for both foreign investors and Zambians to obtain title deeds to customary land. The chiefs had to give approval for the title deeds to be issued (Article 8(2) and (3)). One year later, the Lands (Customary Tenure) (Conversion) Regulations, rerecognised the content of the provisions of the 1995 Lands Act.

The 1995 Lands Act significantly reinforced the power of the local authority to grant land rights and to distribute customary land. As a result of this shift, Chief L of Bemba land introduced and issued independent land rights for customary land. There are many ways in which a local authority can intervene in the issuing of land rights for customary land in Zambia, because the nation contains 73 different ethnic groups, each with its own customs, social life, and political systems (Gadjanova 2017). In Eastern Province, chiefs and lineage seniors provide land certificates and they have reinforced both the commodification of land and increased the inequality of land access (Green and Norberg 2018).

The result of this is that chiefs' approval of title deeds varies widely according to which chiefs are involved, especially because an expanded interpretation of the Lands Act made it possible for chiefs to use their own discretion in granting rights to customary land to the inhabitants of customary land, Zambians, affluent individuals, foreign investors, and foreign companies alike. The 1995 Act recognised existing rights to customary land and eased land right acquisitions by outsiders, foreign investors and Zambian residents (Chitonge et al. 2017; Tobias 2019).

\section{Social Organisation, Agriculture, and Land of the Bemba Chiefdom}

In the late nineteenth century, the Bemba began to form a powerful chiefdom by leveraging their superior military power and commercial activities. The Bemba chiefdom has a centralised authority structure with a paramount chief called a citimukulu at its top. Bemba society includes approximately 30 clans (groups that are thought to have shared ancestors), but all chiefs belong to the clan of the crocodile (the Benangandu). There are 21 chiefs ( $m f u m u$ ) in the Bemba chiefdom, and the position is passed down matrilineally.

Land in Bemba society is categorised into the land (ichalo, pl. ifyalo) of each respective chief. The chiefs are politically unified (Meebelo 1971). The term ichalo has two meanings: (1) the entire territory of the chiefdom of Bembaland; and (2) the territory under the jurisdiction of each chief. In terms of generations and individuals, 
the Bemba people have different attitudes to the chiefs, but they all consider Bemba land to belong to the chiefdom and its chiefs. Bemba chiefs played administrative and judicial roles in the nation both before and after the independence of Zambia (Moore and Vaughan 1994). Local chiefs administer civil justice within their domain, adjudicating land and other property disputes between villagers. When a chief dies, the next chief is determined and dispatched from Kasama District in the Northern Province where the citimukulu resides.

The citimukulu is at the top of the Bemba political system, and is followed by senior and local chiefs. Local chiefs hold autonomy within their own territory and are not considered to be servants of the citimukulu or senior chiefs. The territory of all chiefs is demarcated by borders that were established in the seventeenth century. The inhabitants of a chief's territory are loyal to him and present him with millet, beans, groundnuts, cowpeas, alcohol, chickens, goats, caterpillars, and other gifts. They also perform labour for him by clearing and cultivating arable land (Richards 1939). Chiefs play the role of a guardian to the inhabitants. They watch over the people's lives, mediate disputes among the inhabitants, and conduct trials. A patronage system can be recognised between the chief and members of the Bemba society.

The study area was the X District in Muchinga Province in the Republic of Zambia. The Bemba people living in the study area earn their livelihood based on a particular form of swidden farming called citemene (Kakeya and Sugiyama 1985; Kakeya et al. 2006). In citemene, millet is cultivated one year and groundnuts and bambara nuts are cultivated in the following year. Villagers harvest the cassava planted in the first year, and the following year rows are sometimes formed for the cultivation of beans. After this four-year cycle, the land is allowed to lie fallow. Citemene is a rotation crop system, with local people shifting the location of citemene fields in the surrounding miombo woodland. A fallow period should be more than 50 years for sustainable land use (Oyama 1996). The citemene fields are concentrated within about 5-6 km of roads and cycle times are short to maintain sustainability within the woodlands along roads (Sprague and Oyama 1999).

In 2002, the Zambian government began its Fertiliser Support Programme. This programme enables farmers to obtain agricultural input goods at less-than-market price through subsidies for the purchase of chemical fertilisers and improved seeds for the production of maize, which is a staple food in Zambia. The prices were reduced by $50 \%$ at the beginning of the programme, with a further reduction to $75 \%$ of the price by 2008 , which meant that in 2008 farmers could obtain chemical fertilisers at one quarter of the market price. In 2013, President Sata attempted to reduce or eliminate these subsidies. However, President Sata's sudden death and the subsequent general election of August 2016 meant that the subsidies continue today. These subsidies enable farmers in remote areas, such as X District, to access agricultural input goods and produce maize, which is a cash crop due to its status as a dietary staple. These policies have therefore helped form an affluent class within farming villages and have led to income disparities within these communities (Oyama and Yoshimura 2021).

The Bemba people have a strong sense of pride and identity. Despite their individual differences, they are all aware of their status as subjects of the chiefs of the Bemba chiefdom (mukalochalo). They consider the Bemba land and its natural 
resources to belong to the Bemba chiefdom and its chiefs. The chiefs rule the land and the people within their territory. Permission is required from the chief for people to migrate, establish new villages or for land to be distributed to villages. Without a chiefs' permission, the Bemba cannot clear land for citemene, cut down trees or build houses. Bemba chiefs have great authority (isambu) and people respect their own chiefs and follow the chief's decisions. The next section will examine the granting of rights to customary land by Chief L, whose territory is located in the western part of X District, and charts some of the changes in these rights over time. ${ }^{1}$

\section{The 1995 Lands Act and Customary Land in the Territory of Chief $L$}

After the Lands Act of 1995, land rights began to be granted in the territory of Chief L during the rule of Mr. Y (r. 2003-2007). Mr. Y granted land rights by issuing land allocation forms in a format he himself had decided upon. Because Mr. Y was the son of the chief, he was not the legitimate chief according to the social customs of Bemba society, in that chiefdom is passed down under a matrilineal system. However, as the chief's son, the inhabitants of the area recognised his authority to a certain degree. ${ }^{2}$

These land allocation forms limited the land parcels to be distributed at $75 \mathrm{ha}$. In reality, it was slightly less due to the presence of the village and farmlands. Those hoping to acquire land attempted to secure as broad a swathe of land as possible. Land disputes arose among residents over boundary lines. Mr. Y passed away in 2008 after a long illness. Some residents considered his death to be a punishment for arbitrarily distributing Bemba land to outsiders. After Mr. Y's death, Mr. K became chief. Mr. K was a businessman who ran a bakery, bar, and guesthouse in the local town. Like Mr. Y, he was the chief's son, and was therefore not a legitimate chief in the matrilineal society. Although residents did not directly object to Mr. K's inauguration as chief, they did not participate in the inauguration ceremony.

Mr. K listened to the advice of influential persons in the area and developed a detailed process for the issuance of land allocation forms. While Mr. Y had consulted potential land buyers himself and issued land allocation forms based solely on his own judgement, Mr. K established the CS Land Development Trust (hereinafter referred to as the Land Committee) to deliberate upon, and grant the issuance of, land allocation forms. ${ }^{3} \mathrm{Mr}$. K made himself chair of the committee, appointed influential people from the area, and arranged for the issuance of land allocation forms to be

\footnotetext{
${ }^{1}$ Chief $\mathrm{L}$ is one of the local chief positions within the Bemba chiefdom. To conceal his real name, I have used the initial L to refer to him. I have also used initials for the names of people, villages, and rivers within this chapter.

${ }^{2}$ The granting of a land allocation form and the accompanying land disputes between inhabitants and the social confusion generated when $\mathrm{Mr}$. Y and Mr. K served as Chief L are discussed in detail in Oyama (2016).

${ }^{3}$ The 'CS' in the 'CS Land Development Trust' refers to the name of the first person to serve as Chief $\mathrm{L}$ in 1914. The full name has been concealed.
} 
determined through a council system. The Land Committee was composed of eight members and 11 advisors, resulting in a total of 19 people. Committee members provided Mr. K with suggestions regarding local governance and played the role of cilolo, assisting in both land administration and a broad range of civil court matters.

Between 2003 and 2009, when Mr. Y and Mr. K held the position of Chief L, two forms of documentation regarding land rights to their territory existed side by side: title deeds issued by Zambia's Ministry of Lands and the land allocation forms independently issued by the chief. The acquisition of title deeds required the approval of a chief through a written request, followed by a meeting at the chief's palace (musumba) at which potential buyers would have an audience with the chief, offer tribute, and negotiate. If they were approved, chiefs would give applicants a signed letter as proof of approval, which they could then take to the district office and begin the process of acquiring a title deed. In some cases, applicants obtained the permission of the chief (as needed) but did not consult village heads (doing so was merely optional) and, therefore, some title deeds were issued and land enclosed without the knowledge of the residents and village headmen.

The process of acquiring a land allocation form was quite different. These forms were issued at the discretion of Chief L himself. Unlike title deeds, this form does not permit the sale or purchase of land rights and only makes it possible for the land to be passed down to blood relatives upon the title holder's death. Nonetheless, these forms are considered to guarantee land ownership rights to customary land within the territory of Chief L. Acquiring these forms does not require a visit to the district office or Ministry of Lands (or any other engagement with these bureaucracies), and therefore they are relatively easy to acquire. Inhabitants of the nearby town often used these forms to obtain ownership rights to customary land. These land allocation forms were legally binding because, although the 1995 Lands Act did not contain clear provisions regarding the granting of land rights by chiefs, it did give chiefs authority over the issuance of title deeds, hence, the informal land allocation forms issued in Chief L's territory.

To apply for a land allocation form, applicants needed to supply an application for the purchase of land, an action plan, and a letter of consent from the village committee. Because these forms were not standardised, applications were recorded in the Bemba language on scraps of notebook paper. Action plans described the intended use of the land in detail, e.g., by listing the crops that would be cultivated, the type and number of fruit trees to be planted, the amount of chemical manure to be obtained, the materials to be used in houses or buildings, and the types and numbers of livestock to be raised. The letter of consent contained a signature indicating the approval of the village head.

During Mr. K's time (r. 2008-2009) as Chief L, land allocation forms were issued almost immediately after village headmen approved potential buyers' applications. After submitting the three documents described above and paying an application fee of 190,000 kwacha (US\$60), potential buyers would almost automatically acquire a land allocation form entitling them to 75 ha of land. Although it was the Land Committee's job to examine applicants' intentions and the suitability of their applications closely and carefully, in practice Mr. K had a great deal of influence over 
the issuance of land allocation forms. He often signed and issued them on his own. This meant that some of Mr. K's acquaintances and friends were able to apply to him personally and obtain land allocation forms. This generated many disputes between inhabitants and applicants. In March 2009, Mr. K passed away in a traffic accident, which took place while travelling to attend a festival held in Eastern Province, as a chief. Mr. Y and Mr. K's actions. ie, allocating land to outsiders as illegitimate chiefs, was interpreted by locals to be the cause of their unexpected deaths (Oyama 2016).

A ceremony was held in 2010 to inaugurate Mr. B as the next Chief L. Mr. B belonged to the clan of the crocodile and was therefore of the bloodline of legitimate chiefs. However, he was concerned about the sudden deaths of his predecessors, Mr. Y and Mr. K. Mr. B had been an English teacher at a school in Lusaka, but in 2010, after his retirement, he was called to become Chief L by the paramount chief and senior chiefs. His inauguration ceremony followed Bemba customs, was widely attended, and was both dignified and lavish. At the ceremony, he received the congratulations of the participating local chiefs and other attendees. He declared that to protect his subject's traditional lifestyles, the land of Chief L's territory would no longer be distributed to outsiders. The audience welcomed this announcement with joy.

\section{Local Land Governance Reforms Issued by the Chief}

In December 2011, it was decided that the authority to process and grant land rights should be concentrated in the Land Committee. Both the new Chief L, Mr. B and the members of the Land Committee requested that the wife of the previous chief provide the register book of previously issued land allocation forms, to adjudicate the previous chief's distribution of land, but she claimed that the register book had been lost. In response, the Land Committee and Mr. B decided to invalidate all previously issued land allocation forms. Mr. B did this to establish a precedent whereby land allocation forms would not be issued at a chief's discretion and, therefore, future chiefs would not have to doubt the validity of previously issued land allocation forms. In addition to these reforms, Mr. B instructed the Land Committee to carry out their work in land governance independently of him.

Mr. B made several other changes to the composition of the Land Committee and the role it played. Previously, the committee was responsible for both processing and issuing land allocation forms and adjudicating civil trials. He split the committee into two parts so that it could handle these separate functions more effectively. The Land Committee would continue to process and issue land allocation forms, and ten lay judges (nchenje) would judge civil disputes. This reduced the size of the Land Committee from 19 to ten members. In addition to the nchenje, two elders assumed cilolo responsibilities, advising the chief regarding Bemba traditions, culture, and norms. 
When Zambia reorganised its provincial boundaries in 2011, the territory of Chief L was incorporated into the newly created Muchinga Province. As part of this reorganisation, provincial chiefs (including Mr. B) held a conference with President Sata in December 2012. President Sata had won low-density constituencies in Bembaspeaking provinces, with his ability to generate support in rural areas being derived from his status as a Bemba-speaking presidential candidate (Cheeseman and Hinfelaar 2009). At this conference, President Sata emphasised that the chiefs' role was to promote local development. Mr. B took this as an opportunity to further reform and restructure the Land Committee in the hope that by strengthening inhabitants' land rights he could promote regional development.

As of November 2016, three of ten seats on the Land Committee were empty. The current chairman was Mr. P, who was 40 years old and had served as chairman since 2014. Mr. P was the second-youngest member of the committee, but had demonstrated strong leadership through his intense personality. He suggested to the author that some of the committee's seats remained empty because the committee's work was long-standing, difficult, and carried a heavy responsibility. Moreover, the members received no salary or compensation from the committee. There was also some superstition attached to Land Committee membership. Several Land Committee members had passed away during Mr K's rule, and many people believed that they had died as a punishment for distributing Bemba land to outsiders. As a result, it was difficult to find people who were both suitable committee members and who actually wanted to carry out this kind of work.

The Land Committee did not perform land governance during the rainy/cropping season (November to March). During the dry season, they worked four days a week. On Monday, Tuesday, and Saturday they walked through villages, interviewed potential land buyers, and defined the boundaries between plots of land. The area contained 118 villages and, therefore, this work required committee members to cycle long distances and sometimes stay in villages overnight or for several days. On Thursdays, members deliberated on applications and action plans in the chief's palace, drafted land allocation forms, and performed other office work. As of November 2016, there were more than 80 applicants waiting for land boundaries to be defined and their land allocation forms to be issued. Committee members often received demands, requests, and complaints from these applicants when they were not working and, therefore, found it difficult to relax or maintain a sense that they were not always working. Mr. $P$ stated that he found it difficult to continue working on the Land Committee without compensation, but that requesting a salary from the chief would be discourteous.

The process by which potential buyers received land allocation forms was based on the inauguration of Mr. K to Chief L. Potential buyers applied to the relevant village headmen, and their application was typically approved if nobody lived on or cultivated that land. Then, the potential buyer made a formal request to acquire the land to the village committee. At that stage boundaries were negotiated and trees along the boundary lines were cut down. The potential buyer then purchased an application form from the Land Committee. Unlike the situation during Mr. K's rule, a designated application form was made available. The form defines a household as a husband and wife and their unmarried children, and restricts each household to 
owning a single continuous piece of land and receiving a single land allocation form. Forms can be issued to anyone, not just the Bemba. The price of the application form is $10 \mathrm{kwacha}$ (US\$1) for villagers living in the territory (mukaya, pl. abakaya) and 50 kwacha (US\$5) for outsiders (mwenyi, pl. abenyi) who do not live in Chief L's territory. According to the committee chairman, in the farming villages of Chongwe District near the capital of Lusaka, it costs 350 kwacha (US\$35) to purchase an application form and $500 \mathrm{kwacha}$ (US\$50) to see the application procedure through. Thus, the cost of applying to purchase land in Chief L's territory is relatively low.

Land allocation forms can grant potential buyers up to 50 ha of land. Those who own cows are allocated an additional 20 ha or more, and those who do not are given 15-20 ha of land. The Land Committee's register book indicates the name and gender of the title holder, the name of the village they live in, the amount of land allocated, and the date on which the land boundaries were defined. The register therefore provides a detailed overview of the land allocation process. For example, the register indicates that, as of November 2016, 206 people had acquired land allocation forms. Of these, $151(73 \%)$ were men and $55(27 \%)$ were women. Thirty $(14.6 \%)$ of the names of the title holders are clearly not Bemba names. This is as close as it is possible to get to knowing the distribution of land to different ethnic groups, as this information is not included in the register book.

The Land Committee uses a 50-m piece of hemp cord to measure the boundaries of land. The register indicates that the majority of applications, 109 people $(52.9 \%)$, received land allocation forms valued at 20-50 ha (Table 1). Although the chairman Mr. P indicated that 50 ha was the upper limit of land area distributed to a single person, 59 title holders $(28.7 \%)$ possessed 50 ha or more and six $(2.9 \%)$ possessed 200 ha or more. According to Mr P, these applicants were particularly stubborn during the boundary definition process and asserted that they held vested rights due to their previous use and inhabitation of the land, which made it impossible to reduce the size of their holdings.

The Land Committee issues land allocation forms under the chief's name and does not approve the newly issued title deeds issued by the Ministry of Lands to prevent confusion over sovereignty and due process. The Land Committee receives potential buyers' application forms, action plans, and letters of consent from village

Table 1 Land distributed by Chief L in November 2016

\begin{tabular}{l|c|l}
\hline Registered land size & Number of title holders & $(\%)$ \\
\hline 0 ha $\leqq X<20$ ha & 37 & 18 \\
\hline 20 ha $\leqq X<50$ ha & 109 & 52.9 \\
\hline 50 ha $\leqq X<100$ ha & 35 & 17 \\
\hline 100 ha $\leqq X$ & 24 & 11.7 \\
\hline No data & 1 & 0.4 \\
\hline Total & 206 & 100 \\
\hline
\end{tabular}

Source Data gathered by author 
committees on Thursdays and conducts interviews with them at that time. There are 14 main questions in the interview:

1. How will you use the land that you are hoping to acquire?

2. Do you plan to live on the land?

3. Do you intend to clear the land for citemene or make charcoal on the land?

4. Do you intend to plant trees on the land?

5. Do you plan to raise livestock on the land?

6. Do you intend to build roads on the land?

7. If you are subjected to witchcraft and must move, how do you intend to deal with the land?

8. How will the land be dealt with in the event of your death?

9. If you have no children or family, do you agree to allow the land to revert to the chief?

10. Do you agree not to privatise seasonal wetlands (dambo)?

11. As compensation for the land allocation form, do you agree to pay a $50 \mathrm{~kg}$ bag of maize to the Land Committee each year?

12. Will you participate in jobs related to the village and community?

13. If someone applied to harvest caterpillars on the acquired land, how would you respond?

14. In three years, if you are not able to develop the land as detailed in the submitted action plan, would you agree to return the land?

Chairman Mr. P provided a standard set of responses to these questions:

1. Applicants should describe the materials used in the house, the types of crops and areas of fields, the amount of chemical fertilisers to be applied, the type and number of livestock to be raised, and other relevant items in accordance with the submitted action plan.

2. Absentee landlords are not allowed. All applicants should reside either within the acquired land or in a nearby village.

3. Citemene and the making of charcoal are prohibited as they damage the environment and contribute to climate change. If the applicant responds that they intend to do either, then their application will be denied. However, applicants are permitted to open citemene to clear land for planting maize.

4. Aside from fruit trees (mango, banana, and guava trees), the planting of pines, eucalyptus, and other trees is encouraged.

5. Applicants are encouraged to raise cows and goats, pigs, and chickens.

6. Applicants are obliged to create the roads referred to in question 6 and, therefore, they must be willing to construct roads to provide access to their land.

7. While it is permitted to transfer a land allocation form to children or relatives when moving away from a plot of land, selling the land is not permitted. The sale of buildings, however, is permitted.

8. If a title deed holder dies, it is possible to transfer their rights to their wife or children. 
9. This question attempts to confirm whether the land will be returned to the chief if the applicant has no children or relatives to transfer the land to.

10. Such seasonal wetlands make water resources accessible to all. As water is a shared resource for all inhabitants of the area, the privatisation of marshlands is not permitted.

11. Neglecting to pay this maize tribute for even one year will lead to the loss of land rights. This question is asked to get applicants to make a pledge to continue making these payments.

12. This question establishes an applicant's intention to participate in community work (laying roads, building wells, etc.), which is a condition for acquiring land.

13. Caterpillars are both an important side-dish food for the Bemba and also a valuable source of cash income. It is important to allow people who wish to harvest these caterpillars to do so and thereby contribute to the economic vitality of the area. However, cutting trees down to harvest caterpillars cannot be permitted.

14. This question confirms that the Land Committee will review the circumstances of land use after three years, and seeks the applicant's agreement that if the action plan is not being followed at that time they may be obligated to return some or all of the land to the chief.

After these documents are received and the interview has been conducted, members of the Land Committee inspect the land in question together with the applicant. Together with village headmen and/or members of the village committee, they define the borders of the land by cutting down trees along the border. They then use the hemp rope mentioned above to measure the length of two sides of the land and calculate the total (rectangular) land area.

Nearby residents sometimes attend this process to negotiate the boundaries. This can cause confusion and other problems, especially if the calculated area exceeds 50 ha and the applicant refuses to reduce the size of their holdings. Furthermore, it is difficult for the Land Committee to reduce the area of someone's holdings if the applicant already lives on and is cultivating the land. In such cases, circumstances are often allowed to remain as they are. Calculating the area of the land takes a great deal of time and effort, and it is customary (but optional) for the applicant to provide one chicken to the Land Committee as compensation.

A few days after the boundaries have been defined and the total area calculated, a land allocation form is issued to the applicant and the process is rendered complete. This form is signed by the chief, chairman, clerk of the Land Committee, and one more member of the Land Committee who serves as a trustee. Land allocation forms are issued on a Thursday each week. In 2016, the fee for the issuance was 150 kwacha (US\$15) for land up to 20 ha and an additional 7.5 kwacha (US\$0.75) for each additional hectare. The chief, Mr. B, has complete confidence in the chairman, Mr. P and, therefore, when the chief stays in the capital city of Lusaka, Mr. P serves as the acting chief. He gives progress reports to the chief during the land allocation 
process, but the details of the process are left to him to manage as the committee chairman.

As mentioned above, the Land Committee mandated that those who acquire land allocation forms must pay the committee a $50 \mathrm{~kg}$ bag of maize each year as tribute. The committee's register book indicated that there were a total of 206 land acquirers. According to the Food Reserve Agency's sale price for maize (85 kwacha per bag), this meant that the committee received 17,510 kwacha (US\$1,751) in maize every year. According to Mr. P, this practice arose from the difficulty of collecting large amounts of money or maize from poor residents (mupina, pl. abapina). The committee planned to increase the maize payments in relation to the area of land owned in the future. These regulations were intended not only to enhance the economic life of the region but also to prevent people from being absentee landlords. $30 \%$ of the collected maize is presented to the chief, with the remaining 70\% sold to the Food Reserve Agency or at the general store managed by the committee chairman. Thirty percent of the proceeds to the committee were used to cover expenses incurred by the committee during their duties (the purchase and preparation of stationery, uniforms, shoes, etc.). The remaining $70 \%$ was earmarked for the construction of bridges, road maintenance and repair, and other community development projects.

\section{A New Trend: Villagers Acquiring Land Allocation Forms}

Chief L's territory lies in the western part of X District, the capital of X District. The establishment of planned resettlement and privately owned areas by the government in MK village, $27 \mathrm{~km}$ west of the city of $\mathrm{X}$, has resulted in a lack of land for regional inhabitants, which has, over decades, become a severe problem. For example, a development project on the northern side of the village in the early 1990s was centred on the resettlement of retired soldiers, Tanzania-Zambia Railway (TAZARA) workers and copper miners, and urban-dwellers and farmers from the densely populated border with Tanzania. These resettled people purchased plots in the area and began to operate large-scale farms.

As the land shortage intensified throughout the 2000s, the number of households performing citemene continued to decline. As forested land became scarcer, farmlands shrank in size. This made it difficult for villages to be self-sufficient, decreased the total area of land under citemene and led villagers to complain that their diets were deteriorating (Oyama and Takamura 2001). As of 2007, no villagers had yet acquired land allocation forms.

Land shortages became more severe after 2009. In response, villagers moved, to acquire land allocation forms for themselves. For example, Mr. M, a resident of X township who planned to retire in 2013, decided in 2009 that he wished to move to MK village when he retired. Although he was not related by blood to the village's 
core members, he was related to some long-standing members of the village; thus, the village head permitted him to move there. In 2009, after receiving approval from the chairman of the MK Village Committee, Mr. M applied to the Land Committee and obtained a land allocation form in March 2011. According to the Land Committee's register book, Mr. M obtained 50 ha of land.

However, when the villagers found out that Mr. M had applied for a land allocation form, they felt that they needed to secure land for themselves because outsiders or urban-dwellers had moved to their land. Thus, in June 2009 six villagers settled on the boundaries surrounding their own maize fields and cut down the trees along these boundary lines. Each of these villagers were members of the Village Committee. The committee recognised their intention to acquire land. These land parcels ranged from 8.9 to 39.8 ha in size and averaged 24.7 ha. The boundaries were determined by the Land Committee in October 2010, and the villagers received their land allocation forms in November 2010. Their movement inspired four more villagers to begin the process of acquiring land allocation forms. These four additional villagers applied for lots ranging from 12.0 to 23.3 ha in size.

Mr. M eventually retired and purchased approximately 20 ha of land in July 2015 from a villager who was growing maize on an adjacent plot. He bought the land for $300 \mathrm{kwacha}$ (US\$30). Although the buying and selling of land is prohibited by the Land Committee, land is nevertheless sometimes bought and sold between inhabitants behind closed doors. In August 2015, Mr. M combined these 20 ha with the land he was granted through a land allocation form and put up a boundary fence. He held a total of 72.4 ha of land this way. Mr. M did not actually reside on this land; instead, he cultivated about 2 ha of maize and employed a household of workers to raise 14 cattle on the land. He also owned a maize thresher and miller and has planted papaya, banana, eucalyptus, pine, and other trees on the land.

As of November 2016, nine of the 29 households in MK village (31.0\%) had acquired land allocation forms. Seven of the title holders in these nine households were men and two were women. Of the women, one was the head of her household. She was born and raised in MK village and became the title holder in place of her husband, who was born in a different village. The other said in an interview that she had acquired the land for her children:

As long as I am alive, I have strong family connections and relationships with important core members [mukaya, pl. abakaya] in the village, so I am not worried and know that I can cultivate my fields. However, in recent years, not only my relatives but also outsiders [mwenyi, pl. abenyi] have come to live in the village, so if I die my children may have difficulty finding land to cultivate. In order to leave a foundation for their livelihoods [umufula], I acquired land rights as a form of property [icisuma].

She also revealed that her relationship with her husband was not going well when she acquired a land allocation form and became a title holder. Thus, the land provided a way for her to provide for herself after her impending divorce.

As of 2016, 15 of the 29 households living in MK village (51.7\%) practiced citemene. This represented an increase in the number of households not practising citemene. Villagers stated in interviews that it had become difficult to earn a living through citemene, and that producing maize using government-subsidised chemical 
fertilisers and improved maize seeds helped them to be more self-sufficient. In addition, as of 2016, 15 of these households had brick houses with galvanised iron roofs, 16 owned mobile phones, and eight owned solar panels. In 2007, no households had any of these features. This indicates that there has been a sudden increase in the household accumulation of capital. At the same time, the trend toward obtaining land allocation forms and establishing land ownership has become stronger within the local villages.

\section{Friction Between Local Residents and Recipients of Land Allocation Forms}

\subsection{Friction with Local Residents}

Mr. L is a 71-year-old man who moved from X township to ND village in 1998. Prior to moving, he worked for 20 years at a company that manages an oil pipeline connecting Tanzania and Zambia. Mr. L was born and raised in Western Province and is a member of the Lozi people. He relocated to ND village because his wife is a Bemba. When Mr. B became Chief L in 2010, Mr. L obtained approval from the ND village headman and applied for a land allocation form. He received his application form in 2014 and the boundaries of his land were defined in June 2015. The total recorded area of his land is $50 \mathrm{ha}$. Mr. L cultivates citemene on this land every year as well as 0.62 ha of maize fields.

In November 2016, three inhabitants of ND village felled trees to enable citemene, maize cultivation, and charcoal production on Mr. L's private land. They continued doing so, even after he explained that he had acquired a land allocation form, on the grounds that he was Lozi. Given the land shortages facing ND village, some villagers did not accept that Mr. L had acquired land there. Thus, the structure of the land allocation process and other circumstances, such as land shortages, have created conflicts and confusion during the land allocation process.

\subsection{Leasehold Changes Accompanying Changes in Title Holders}

Mr. T, the founder of ML village, was born in 1936. He was the grandson of Mr. CS, who was the first-generation Chief L. He was employed in the ticket office at the United Bus Company of Zambia from 1964 to 1988, after which he returned to ML village. Mr. T did not settle along a road with existing settlements but, instead, built his house along the $\mathrm{R}$ river. Using the wealth he had amassed in the city, he purchased a cow and worked to raise it, practiced citemene, and cultivated maize. In 1990, he acquired a title deed from the Ministry of Lands. When Mr. T died in 2004, 
his son Mr. A took ownership of the title deed; however, his son lacked the money to fully use and manage this land. Given these circumstances, he allowed married couple $\mathrm{C}$, who were living in ML village, to grow cassava along the riverbank on the southern side of his land. These cassava fields were not very large ( 0.4 ha) but they were located on fertile soil, and thus grew large enough to be a substantial source of food during the rainy season.

Mr A needed money to move to the city, so he visited nearby MK village to find a potential buyer for his land. There he met married couple $\mathrm{O}$ who were considering buying land as an asset. The husband of couple $\mathrm{O}$ was a teacher at the university in Kasama (the provincial capital of the Northern Province) and a member of the Kaonde people, while his wife was from a village adjacent to MK village. In 2012, the couple paid Mr. A 10 million kwacha (about US\$1,985) and entered into a contract with him by which they received the rights to 183 ha of land, i.e., a value of about US\$10.8 per hectare. The wife of couple O told the author that she considered the price of land in Chief L's territory to be cheap and expected the price of land to jump sharply in the future and that, therefore, it was a good investment.

To define the boundaries of their plot, the father of the wife of couple O (Mr. D) cut down the trees along the boundary line. While doing this work he realised that cassava was being grown along the river. He pulled up all of the cassava without receiving permission from or notifying anyone. He knew that married couple $\mathrm{C}$ were cultivating the cassava and some people accused him of pulling it up intentionally. Both Mr. D and the mother of the wife of couple $\mathrm{C}$ live in $\mathrm{MK}$ village, and are cousins. However, the relationship between the two is fraught. Mr. D's actions meant that married couple $\mathrm{C}$ were unable to harvest any cassava during the rainy season in 2014, and were barely able to eke out a living.

As it is not permitted to issue new title deeds in Chief L's territory, couple O later applied to the Land Committee in the hopes of acquiring a land allocation form. After going through the formal process, they acquired a form in the name of the wife of couple $\mathrm{O}$ in November 2015 (she was chosen as the title holder because she was raised in the region and had many relations nearby). The couple employed villagers to build a house with a corrugated iron roof along the L river and began to clear the surrounding forest. However, as of November 2016, the house had no door, no crops were being cultivated on the land that had been cleared, and the land remained insufficiently managed.

\section{The chief's Revocation of Title Deeds and Reversion to Customary Land}

In 1988, ex-serviceman Mr. X obtained a title deed to land on the southern side of MK village. He obtained this deed directly from the Ministry of Lands without the mediation of the chief or nearby village head. The area of this privately owned land was approximately 1250 ha. Before the 1995 Lands Act was enacted, the Ministry 
of Lands accepted applications for title deeds and issued title deeds to applicants regardless of the knowledge or approval of the chief, village headman, or local inhabitants.

After acquiring the title deed, Mr. X continued to live in Lusaka. His younger brother managed his vast area of private land and lived in the nearby $L$ village with his wife and children. He possessed a licence to own a rifle, which he always carried when he entered the forests owned by his elder brother. If he found villagers felling trees for citemene or gathering caterpillars or honey within their land, he would threaten them by firing live rounds from the rifle. As a result, inhabitants of the surrounding villages refused to enter Mr. X's lands. This situation did not change through the reigns of successive chiefs and continues up to the present day. ${ }^{4}$ Thus, villagers from MK village were unable to rely on citemene to earn a living, as the government's resettlement scheme was on the northern side of town and Mr. X's vast privately owned estate was on the southern side.

In response, chief Mr. B gathered the inhabitants of MK village and the surrounding villages and held a meeting so that they could voice their grievances in April 2016. At the meeting, he suggested that land disputes between inhabitants should be reported to the chief's palace and that those hoping to acquire land allocation forms should come to the palace. The villagers reported that there was not enough land for them to practise citemene and that this had resulted in them becoming impoverished and underfed. They also petitioned him to return Mr. X's privately owned land to the village as communal land. The chief ordered Mr. P to investigate and resolve the issue.

Mr. P and the members of the Land Committee interviewed Mr. X and asked him why the villagers could not use the land in question. This was especially troubling given the land's great productivity; according to the title deed from 1988, Mr. X owned two tractors, had 30 ha of cultivated maize fields, was raising 45 cows and 60 goats, and had 200 mango trees, 150 guava trees, and a large number of pine trees on his property. However, upon investigation Mr. X had no tractors, had not built a house on the land, had not cultivated more than 0.5 ha of maize fields, and possessed only a few mango trees and 20 goats. The land in question was clearly not being used effectively. Mr. X's younger brother explained that he had not been able to work the land for 30 years because his relatives had taken the money he had planned to use to develop the land.

The investigation also found that Mr. X had not paid the government the fixed asset tax of 15,000 kwacha per year (US\$1500). Because he had not paid this tax and not fulfilled his duty to improve the land for decades, the Land Committee determined that the land should be returned to the chief if $\mathrm{X}$ was unable to renew the title deed with the Ministry of Lands within 30 days. When he had not done so, his holdings were reduced to 100 ha along the $L$ river and the rest was returned to the chief as customary land. The chief determined that the land should belong to MK village,

\footnotetext{
${ }^{4}$ The successive chiefs and their periods in office are: KP (r. 1984-1998), MM (r. 1998-2003), Y (r. 2003-2007), K (r. 2008-2009) and B (r. 2010-).
} 
gave the village headman responsibility for the use of the land and recognised the villagers' rights to use the land.

The headman of $\mathrm{CH}$ village, which is adjacent to MK village, objected to this decision. He complained that because a government resettlement scheme was located on the northern side of $\mathrm{CH}$ village and the village faced a severe land shortage, the villagers of $\mathrm{CH}$ village should also have the right to use Mr. X's formerly owned land. This complaint was rejected by the chief because there was abundant land in $\mathrm{CH}$ village. As a result, the headman of $\mathrm{CH}$ village drew boundary lines and began the process of applying for his own land allocation form. This process has become the source of an intense dispute between the villages.

After the land was released to them, villagers from MK village promptly entered the land and began to practise citemene. By November 2016, two households had already cleared land for citemene and burned the trees and brush they had cleared. Men from the village were delighted to clear the extensive forest for citemene, for the first time in many years, and built huts to live in while cultivating the land. This kind of advance guard is called baleya intanshi in the Bemba language. After they had enclosed suitable land for citemene, villagers began talking about how the villagers were trying to take the land for themselves. They were thus motivated to practise large-scale citemene on this land over the following year.

The Bemba people emphasise how the old 'era of farming only to eat' (inshita yakurya fye) has ended and has given way to the 'era of thinking ahead' (inshita yakutontonkanya ifyakuntanshi). They see practising citemene and acquiring a land allocation form as important and positive acts. Those who lack the intention to do so are frowned upon as balishalila, or people who only produce enough food for themselves to consume in the short term through citemene. This latter group is ridiculed by the former for not adapting to the changing times, as private land ownership increases and land shortages become more severe.

\section{Conclusion}

Although the 1995 Lands Act did not clearly recognise the chiefs' authority to distribute customary land and the right to use it, the Act mandated that chiefs' approval was a necessary step in acquiring a title deed to customary land. In this way, the Zambian government has situated chiefs at the centre of the regional development process and strengthened their authority over the land. This move has led chiefs to render land allocation forms issued by chiefs before 1995 invalid and to reform the processes governing the acquisition of land allocation forms. As a result, landowners holding old, invalid land allocation forms must now go through the new process and acquire new forms, title deeds issued by the Ministry of Lands have been rendered invalid, and new title deeds cannot be issued within a chief's territory without their consent. The chiefs' new-found power is accompanied by powerful mechanisms to compel potential buyers to contribute to their communities. These changes mean that chiefs in farming village communities have strengthened their 
authority over both the land and its inhabitants. This form of land governance is strongly autonomous in that it does not permit the participation of the surrounding chiefs or state governmental institutions.

The establishment of land ownership rights to customary land has brought about land enclosure. While this has created a situation in which wealthy people, retirees, and villagers with foresight have taken the initiative in acquiring land ownership rights, it has also led villagers to seek land ownership to protect their customary lands and lifestyle. It is important that land ownership rights are not only supported by the Lands Act and the chiefs but are also recognised by the inhabitants of farming villages. In adjudicating land disputes, it is necessary to determine the lawfulness of land ownership according to who has the land rights, who actually cultivates the land, and who lives on the land. Claims to ownership need to be examined within the social and historical contexts of the community in question.

As land becomes scarcer, a trend toward acquiring land ownership is expected to accelerate among farming village communities where property has only begun to hold value. With the increasing demand for land, the anxiety among local people over land scarcity will strengthen the political power and authority of the chiefs. As described in the Chitonge chapter, the influence of traditional leaders is not only a result of cultural and ethnic allegiances but is also the result of politicians attempting not to antagonise the rural electorate. The residents of local communities in Zambia emphasise the importance of an autonomous lifestyle based on self-sufficiency that is not influenced by economic and political fluctuations. Land ownership rights in Zambia's farming village communities should therefore be regulated through complex political dynamics, which are a function of the 1995 Lands Act, the intentions of the chiefs, national economic policies, and the social relationships among local inhabitants. The various stakeholders, institutions and the need for social capital have generated a complex situation surrounding customary land rights.

\section{References}

Ault, D.E., and G.L. Rutman. 1993. Land scarcity, property rights and resource allocation in agriculture: Eastern and southern Africa. South African Journal of Economics 61: 32-44.

Boone, C. 2014. Property and political order in Africa: Land rights and the structure of politics. New York: Cambridge University Press.

Brown, T. 2005. Contestation, confusion and corruption: Market-based land reform in Zambia. In Competing jurisdictions: Settling land claims in Africa, eds. E. Sandra, M. Spierenburg, and W. Harry, 79-102. Leiden and Boston: Brill.

Chanock, M. 1998. Law, custom, and social order: The colonial experience in Malawi and Zambia. Portsmouth: Heinemann.

Cheeseman, N., and M. Hinfelaar. 2009. Parties, platforms, and political mobilization: The Zambian presidential election of 2008. African Affairs 109: 51-76.

Chitonge, H., O. Mfune, B.B. Umar, G.M. Kajoba, D. Banda, and L. Ntsebeza. 2017. Silent privatisation of customary land in Zambia: Opportunities for a few, challenges for many. Social Dynamics 43: $82-102$. 
Gadjanova, E. 2017. Ethnic wedge issues in electoral campaigns in Africa's presidential regimes. African Affairs 116: 484-507.

Green, E., and M. Norberg. 2018. Traditional landholding certificates in Zambia: Preventing or reinforcing commodification and inequality. Journal of Southern African Studies 44: 613-628.

Gulliver, P.H. 1961. Land shortage, social change and social conflict in East Africa. Journal of Conflict Resolution 5: 16-26.

Kajoba, G.M. 2004. Land reform and related issues in Zambia. In Land reform and tenure in southern Africa: Current practices, alternatives and prospects, ed. M. Munyuki-Hungwe, 188-202. Harare: Savle Press.

Kakeya, M., and Y. Sugiyama. 1985. Citemene, finger millet and Bemba culture: A socioecological study of slash-and-burn cultivation in northern Zambia. African Study Monographs Supplementary 4: 1-24.

Kakeya, M., Y. Sugiyama, and S. Oyama. 2006. The citemene system, social leveling mechanism, and agrarian changes in the Bemba villages of northern Zambia: An overview of 23 years of 'fixed-point' research. African Study Monographs 27: 27-38.

Malambo, A.H. 2013. Land administration in Zambia since 1991: History, opportunities and challenges. Global Advanced Research Journal of History, Political Science and International Relations 2 (4): 53-66.

Mamdani, M. 1996. Citizen and subject: Contemporary Africa and legacy of late colonialism. Princeton: Princeton University Press.

Meebelo, H.S. 1971. Reaction to colonialism: A prelude to the politics of independence in northern Zambia, 1893-1939. Manchester: Manchester University Press.

Moore, H.L., and M. Vaughan. 1994. Cutting down trees: Gender, nutrition, and agricultural change in the Northern Province of Zambia, 1890-1990. London: Heinemann.

Moyo, S. 2007. Land policy, poverty reduction and public action in Zimbabwe. In Land, Poverty and livelihoods in an era of globalization, ed. H. Akram-Lodhi, S.M. Borras, and C. Kay, 344-382. London and New York: Routledge.

Mvunga, M.P. 1980. The colonial foundations of Zambia's land tenure system. Lusaka: Historical Association of Zambia.

Mvunga, M.P. 1982. Land law and policy in Zambia. Gweru: Mambo Press.

Oyama, S. 1996. Regeneration process of the miombo woodland at abandoned citemene shifting cultivation field in northern Zambia. African Study Monographs 17 (3): 101-116.

Oyama, S. 2016. Guardian or misfeasor? Chief's roles in land administration under the new 1995 Land Act in Zambia. In What colonialism ignored: 'African potentials' for resolving conflicts in southern Africa, ed. S. Moyo and Y. Mine, 103-128. Bamenda: LANGAA Publisher.

Oyama, S., and Y.T. Takamura. 2001. Agrarian changes and coping strategies for subsistence of Bemba shifting cultivators in northern Zambia in the mid-1990's. Journal of Tropical Agriculture 45 (2): 84-97.

Oyama, S., and Y. Yoshimura. 2021. Levelling mechanisms and growing economic disparities associated with piecework performed by the Bemba people of Zambia. In Development and subsistence in globalising Africa: Beyond the dichotomy, eds. M. Takahashi, S. Oyama, and H.A. Ramiarison, 75-98. Bamenda: Langaa RPCIG.

Richards, A.I. 1939. Land, labour and diet in Northern Rhodesia: An economic study of the Bemba tribe. London: Oxford University Press.

Roberts, A. 1976. A history of Zambia. New York: Africana Publishing Company.

Sprague, S.D., and S. Oyama. 1999. Density and distribution of citemene fields in a miombo woodland environment in Zambia. Environmental Management 24: 273-280.

Times of Zambia. 2012a. Sata assures chief of rural uplift, 29 November. https://allafrica.com/sto ries/201211290483.html. Accessed 19 April 2021.

Times of Zambia. 2012b. Sata meets Muchinga Chiefs. 12 December. https://allafrica.com/stories/ 201212120328.html. Accessed 19 April 2021. 
Tobias, H. 2019. The different meaning of land in the age of neoliberalism: Theoretical reflections on commons and resilience grabbing from a social anthropological perspectives. Land 8: 104. https://doi.org/10.3390/land8070104.

von Blanckenburg, P. 1993. Large farms as object of land reform: The case of Zimbabwe. Quarterly Journal of International Agriculture 32: 351-370.

Zambia Daily Mail. 2016. Chitimukulu offers 100 hectares for oil refinery, 24 October.

Open Access This chapter is licensed under the terms of the Creative Commons Attribution 4.0 International License (http://creativecommons.org/licenses/by/4.0/), which permits use, sharing, adaptation, distribution and reproduction in any medium or format, as long as you give appropriate credit to the original author(s) and the source, provide a link to the Creative Commons license and indicate if changes were made.

The images or other third party material in this chapter are included in the chapter's Creative Commons license, unless indicated otherwise in a credit line to the material. If material is not included in the chapter's Creative Commons license and your intended use is not permitted by statutory regulation or exceeds the permitted use, you will need to obtain permission directly from the copyright holder.

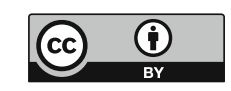

